\title{
Improving Occupational Health and Safety (OHS) implementation in construction project in Bali
}

\author{
Gusti Dharmayanti ${ }^{1 *}$, Sien Pramana ${ }^{l}$, Astawa Diputra ${ }^{l}$, and Ariany Frederika ${ }^{l}$ \\ ${ }^{1}$ Department of Civil Engineering, Universitas Udayana, Bali, Indonesia
}

\begin{abstract}
Optimal Occupational Health and Safety (OHS) implementation to achieve zero accident becomes the demand for construction service providers in realizing a qualified infrastructure, including for construction industry in Bali and Indonesia as general. This study aims to investigate the barriers of OHS implementation faced by contractors in Bali, and to formulate the efforts to improve the implementation. Collected data from a questionnaire survey were analysed using Analytic Hierarchy Process (AHP) to determine the priority level of the identified barriers. The results suggested that the barriers on the implementation of OHS which was sorted from the most important included Limited funding for OHS (3.231), Low OHS priority by company management (2.020), Low culture and discipline to implement OHS (1.031), Lack of knowledge about OHS (0.725), Weak supervision (0.478), Weak application of sanctions from the company (0.340), and Contractor forced to work until late at night (0.230). The related efforts were formulated based on semi-structured interviews recommended that the cost of implementing OHS including the required methods and equipment should be covered in the planning stage, and socialization, supervision and strict sanctions against violations of OSH implementation needs to be applied.
\end{abstract}

\section{Introduction}

The construction industry in Indonesia growth considerably, including in Bali as one of the tourism destinations that have the significant development of infrastructure to support tourism activities. Many of large-scale hotel projects constructed in Bali is located in the south part, i.e., in the Badung Regency and Denpasar. The more complex of activities in the project may result in more risks for the parties involved in the construction. According to the Social Security Organizing Body of Health, there were 105,182 cases of working accidents that caused 2395 fatalities in 2015 [1]. This situation can get worse if a construction company does not optimally implement Occupational Health and Safety (OHS) in their project as the preventive strategy.

\footnotetext{
*Corresponding author: candra_dharmayanti@unud.ac.id
} 
The implementation of OHS in Indonesia is controlled by The Government Regulation No. 50/2012. OHS is a part of company management that aims to manage risks associated work activities, to create a workplace that safe, efficient and productive. Based on the current research, the implementation of OHS in the construction industry in Indonesia still needs to be improved [2-4]. Several barriers toward the OHS implementation have been indicated, such as lack of funding, lack of knowledge related to OHS, and low supervision enforcement [5-8].

A large-scale project usually requires the contractors (bidders) to provide certification of OHS. However, when viewed from the risk of work accidents, two-story building projects also potentially pose the risks of workplace accidents, such as workers who fall from the second floor, workers are hit by construction materials, collapsing floor plates, accidents due to the use of work tools, falling material, and so on. Therefore, the implementation of OHS should not be limited to a large scale project.

From the field observations on building projects in Bali (covered two to four-story buildings), the workers who do not use personal protective equipment (PPE) are still frequently seen. The use of PPE as a form of OHS application is considered as an additional expenditure of project costs. Therefore, this cost has been excluded by the contractor to win a project, since most project owners prioritize the lowest bid. Whereas in the event of a work accident, potential losses incurred can cause additional project costs, insured costs, and can impact on the reputation of the contractor (REF). Thus, the application of the OHS element should be considered by all contractors as an action to prevent workplace accidents. This study aimed to determine the most influential constraints in implementing OHS in construction companies in Bali, as well as formulating efforts to improve the implementation of OHS.

\section{OHS implementation in the indonesian construction}

The implementation Occupational Health and Safety (OHS) in the construction industry in Indonesia is regulated by Government Regulation (PP No. 50 Year 2012), which aims: to improve the effectiveness of planned, measurable, structured and integrated protection of occupational safety and health; to prevent and reduce accidents, work and disease resulting from work by involving elements of management, workers and unions; and to create a safe, comfortable and efficient workplace to boost productivity.

Construction work involves a lot of equipment, both complicated and straightforward, from light to heavy. The use of this equipment improperly is likely to cause an accident. Accidents are adverse events, which are unexpected, not expected and not intentionally conducted. According to [9], there are four factors causing work accidents in construction, that is the worker itself, the construction method, equipment, and management. Although humans have been careful, if the environment does not support (unsafe), then accidents can also occur and vice versa. Therefore, guidance is needed on how to work that meets the principles of safety.

The implementation of OHS in Indonesia is in the range of $30 \%$ to $80 \%$, as indicated in several previous studies which state that the application of OHS in Indonesia [2-4]. Various obstacles affect the lack of implementation of OHS in Indonesia, including limited funds, lack of knowledge, and weak supervision [5-8]. Given the importance of OHS and to maximize the implementation of OHS, it is necessary to identify the barriers that hinder the implementation of OHS. Based on the literature review, the barriers that can impede the implementation of OHS were summarized in Table 1. 
Tabel 1. Barriers to the implementation of OHS.

\begin{tabular}{|c|c|c|c|c|c|c|}
\hline \multirow{2}{*}{ Factors } & \multicolumn{6}{|c|}{ References* } \\
\hline & [5] & [8] & [7] & [6] & [10] & [11] \\
\hline Limited OHS funds & • & • & $\bullet$ & & • & \\
\hline Low OHS priority by company management & $\bullet$ & & & & • & \\
\hline Lack of knowledge about OSH & $\bullet$ & $\bullet$ & & • & & \\
\hline Weak supervision & • & & • & & • & \\
\hline Weak sanction from the company & & & • & & • & \\
\hline Low culture and discipline of implementing OHS & & $\bullet$ & & & • & \\
\hline The contractor forced the workers to work until late at night & & & & & & • \\
\hline
\end{tabular}

Several efforts to overcome the obstacles to the implementation of OHS based on previous research are presented in Table 2 .

Tabel 2. Efforts to improve the implementation of OHS.

\begin{tabular}{|c|c|c|c|c|}
\hline \multirow{2}{*}{ Efforts } & \multicolumn{4}{|c|}{ References* } \\
\hline & [10] & [2] & [3] & [12] \\
\hline Include the cost for equipment of OSH in the budget plan & - & & - & \\
\hline Periodic socialization of OHS implementation from the government & - & & & \\
\hline Issue a firm OSH policy & - & & - & \\
\hline Provide strict sanctions if it does not implement OHS & - & & & \\
\hline Improve supervision of the implementation of OHS in the project & & - & & \\
\hline $\begin{array}{c}\text { Give an adequate break before conducting overtime works until late at } \\
\text { night }\end{array}$ & & & $\bullet$ & \\
\hline $\begin{array}{l}\text { Providing training regarding OHS (i.e.: regulations, SOP, personal } \\
\text { protective equipment) }\end{array}$ & & & & $\bullet$ \\
\hline
\end{tabular}

\section{Methodology}

Data collection was conducted through a questionnaire survey that was compiled by seven variables of barriers based on the literature review (as presented in Table 1). The questionnaires were distributed to 10 respondents who were experts with one of the criteria as follows: 1) Bachelor or equal with work experience in the OHS field for at least 2 years, or 2) Diploma or equal with work experience in the OHS field for at least 4 years, or 3) Having a certificate of expertise in the OHS field. 
The collected data were analyzed using the Analytical Hierarchy Process (AHP) that is a decision support model developed by Thomas L. Saaty [13]. This method is used to describe problems into a complex multi-factors hierarchy.

Table 3. The level of importance scale [13].

\begin{tabular}{|c|c|}
\hline Level of importance & Definition \\
\hline 1 & Equally important \\
\hline 3 & A little more important \\
\hline 5 & Clearly more important \\
\hline 7 & Very clearly more important \\
\hline 9 & Definitely/absolutely more important (extreme interests) \\
\hline $2,4,6,8$ & If in doubt between two adjacent values \\
\hline $1 /(1-9)$ & Reverse the level of importance on a scale of $1-9$ \\
\hline
\end{tabular}

\section{Results and discussion}

\subsection{Barriers on the implementation of SMK3}

Seven variables of barriers to the implementation of OHS obtained from the literature review were used to develop a questionnaire that was distributed to 10 respondents who were experts in the OHS field.

Table 4. Variable of barriers.

\begin{tabular}{|c|c|}
\hline Variable ID & Barriers \\
\hline F1 & Limited OHS funds \\
\hline F2 & Low OHS priority by company management \\
\hline F3 & Lack of knowledge about OSH \\
\hline F4 & Weak supervision \\
\hline F5 & Weak sanction from the company \\
\hline F6 & Low culture and discipline of implementing OHS \\
\hline F7 & The contractor forced the workers to work until late at night \\
\hline
\end{tabular}

The process of AHP is described as follow: 1) Preparation of Initial Pairing Comparison Matrix. Pairwise comparison matrices are arranged based on the value of each variable, as can be seen in Table 5. 2) Normalization of pairwise comparison matrix. A pairwise comparison matrix is normalized by dividing the value of each variable with the sum of each variable column. The result is presented in Table 6. 3) Calculation of weight value. The weight value is calculated by averaging every row of the normalization matrix, as presented in Table 6 (the last column). 
Table 5. Pairwise comparison matrix between barrier's variables.

\begin{tabular}{|c|c|c|c|c|c|c|c|}
\hline & F1 & F2 & F3 & F4 & F5 & F6 & F7 \\
\hline F1 & 1.000 & 3.000 & 5.000 & 7.000 & 7.000 & 5.000 & 7.000 \\
\hline F2 & 0.333 & 1.000 & 3.000 & 5.000 & 5.000 & 5.000 & 5.000 \\
\hline F3 & 0.200 & 0.333 & 1.000 & 3.000 & 3.000 & 0.333 & 3.000 \\
\hline F4 & 0.143 & 0.200 & 0.333 & 1.000 & 3.000 & 0.333 & 3.000 \\
\hline F5 & 0.143 & 0.200 & 0.333 & 0.333 & 1.000 & 0.333 & 3.000 \\
\hline F6 & 0.200 & 0.200 & 3.000 & 3.000 & 3.000 & 1.000 & 5.000 \\
\hline F7 & 0.143 & 0.200 & 0.333 & 0.333 & 0.333 & 0.200 & 1.000 \\
\hline
\end{tabular}

Tabel 6. Weight value of barrier's variables.

\begin{tabular}{|c|c|c|c|c|c|c|c|c|}
\hline & F1 & F2 & F3 & F4 & F5 & F6 & F7 & Weight value (average) \\
\hline F1 & 0.463 & 0.584 & 0.385 & 0.356 & 0.313 & 0.410 & 0.259 & 0.396 \\
\hline F2 & 0.154 & 0.195 & 0.231 & 0.254 & 0.224 & 0.410 & 0.185 & 0.236 \\
\hline F3 & 0.093 & 0.065 & 0.077 & 0.153 & 0.134 & 0.027 & 0.111 & 0.094 \\
\hline F4 & 0.066 & 0.039 & 0.026 & 0.051 & 0.134 & 0.027 & 0.111 & 0.065 \\
\hline F5 & 0.066 & 0.039 & 0.026 & 0.017 & 0.045 & 0.027 & 0.111 & 0.047 \\
\hline F6 & 0.093 & 0.039 & 0.231 & 0.153 & 0.134 & 0.082 & 0.185 & 0.131 \\
\hline F7 & 0.066 & 0.039 & 0.026 & 0.017 & 0.015 & 0.016 & 0.037 & 0.031 \\
\hline
\end{tabular}

4) Calculation of variable priority value. Priority criteria value is obtained by multiplying the comparison matrix in pairs with the weight value matrix. The most important criteria or priorities are indicated by the highest priority value. The calculation is demonstrated as follow:

\begin{tabular}{|c|c|c|c|c|c|c|c|}
\hline & F1 & F2 & F3 & F4 & F5 & F6 & F7 \\
\hline F1 & 1.000 & 3.000 & 5.000 & 7.000 & 7.000 & 5.000 & 7.000 \\
\hline F2 & 0.333 & 1.000 & 3.000 & 5.000 & 5.000 & 5.000 & 5.000 \\
\hline F3 & 0.200 & 0.333 & 1.000 & 3.000 & 3.000 & 0.333 & 3.000 \\
\hline F4 & 0.143 & 0.200 & 0.333 & 1.000 & 3.000 & 0.333 & 3.000 \\
\hline F5 & 0.143 & 0.200 & 0.333 & 0.333 & 1.000 & 0.333 & 3.000 \\
\hline F6 & 0.200 & 0.200 & 3.000 & 3.000 & 3.000 & 1.000 & 5.000 \\
\hline F7 & 0.143 & 0.200 & 0.333 & 0.333 & 0.333 & 0.200 & 1.000 \\
\hline
\end{tabular}

\begin{tabular}{|c|c|c|c|}
\hline $\begin{array}{l}\text { Weight } \\
\text { value }\end{array}$ & \multirow{8}{*}{$=$} & $\begin{array}{c}\text { Priority } \\
\text { value }\end{array}$ & Rank \\
\hline 0.396 & & 3.231 & 1 \\
\hline 0.236 & & 2.020 & 2 \\
\hline 0.094 & & 0.725 & 4 \\
\hline 0.065 & & 0.478 & 5 \\
\hline 0.047 & & 0.340 & 6 \\
\hline 0.131 & & 1.031 & 3 \\
\hline 0.031 & & 0.230 & 7 \\
\hline
\end{tabular}


5) Consistency test. The consistency test aims to examine if the data obtained is close to perfect, therefore it will produce valid decisions. The following are the calculation of the consistency.

Step 1. Calculation value of $\lambda \max$.

$$
\begin{aligned}
& \lambda \text { maks }=\frac{1}{\mathrm{n}} \times\left(\frac{\mathrm{A}_{1}}{\mathrm{~W}_{1}}+\frac{\mathrm{A}_{2}}{\mathrm{~W}_{2}}+\frac{\mathrm{A}_{3}}{\mathrm{~W}_{3}}+\ldots+\frac{\mathrm{A}_{\mathrm{n}}}{\mathrm{W}_{\mathrm{n}}}\right) \\
& \lambda \text { maks }=\frac{1}{7} \times\left(\frac{3.231}{0.396}+\frac{2.020}{0.236}+\frac{0.725}{0.094}+\frac{0.478}{0.065}+\frac{0.340}{0.047}+\frac{1.031}{0.131}+\frac{0.230}{0.031}\right)=7.756
\end{aligned}
$$

Step 2. Calculation of CI value.

$$
\begin{aligned}
& \mathrm{CI}=(\lambda \text { maks }-\mathrm{n}) /(\mathrm{n}-1) \\
& =(7.756-7) /(7-1)=0.126
\end{aligned}
$$

Step 3. Calculation and testing of CR value.

$$
\begin{aligned}
\mathrm{CR} & =\mathrm{CI} / \mathrm{RI} \\
& =0.126 / 1.32=0.095
\end{aligned}
$$

(data is consistent as $\mathrm{CR}$ value is lower than 0.1 ).

According to the result of priority values, the most influential barriers (constraints) are ranked as presented in Table 7.

Tabel 7. Priorities values of barriers.

\begin{tabular}{|c|r|c|c|}
\hline Variable ID & Barriers variable & Rank & $\begin{array}{c}\text { Priorities } \\
\text { value }\end{array}$ \\
\hline F1 & Limited OHS funds & 1 & 3.231 \\
\hline F2 & Low OHS priority by company management & 2 & 2.020 \\
\hline F6 & Low culture and discipline of implementing OHS & 3 & 1.031 \\
\hline F3 & Lack of knowledge about OSH & 4 & 0.725 \\
\hline F4 & Weak supervision & 5 & 0.478 \\
\hline F5 & Weak sanction from the company & 6 & 0.340 \\
\hline F7 & The contractor forced the workers to work until & 7 & 0.230 \\
\hline
\end{tabular}

\subsection{Efforts to address barriers of OHS implementation}

In order to formulate the efforts to address the identified barriers, further data collection was carried out through a semi-structured interview, involving three respondents who were experts in the field of OHS, including Site manager, Project manager, and Safety supervisor. The result of semi-structured interview is presented in Table 8. 
Tabel 8. Efforts related to the prioritized barriers on OHS implementation.

\begin{tabular}{|c|c|c|c|c|}
\hline \multirow{3}{*}{ Barriers } & \multicolumn{4}{|c|}{ Identified efforts based on: } \\
\hline & \multirow{2}{*}{ Literature } & \multicolumn{3}{|c|}{ A semi-structured interview } \\
\hline & & R1 & $\mathbf{R 2}$ & R3 \\
\hline $\begin{array}{l}\text { Limited OHS } \\
\text { funds (F1) }\end{array}$ & $\begin{array}{l}\text { Include the cost } \\
\text { of OHS into the } \\
\text { budget plan. }\end{array}$ & $\begin{array}{l}\text { Include the cost of } \\
\text { OHS into the budget } \\
\text { plan. }\end{array}$ & $\begin{array}{l}\text { Include the cost } \\
\text { of OHS into the } \\
\text { budget plan. }\end{array}$ & $\begin{array}{l}\text { Replace the OHS } \\
\text { equipment with } \\
\text { the one that more } \\
\text { simple. }\end{array}$ \\
\hline $\begin{array}{l}\text { Low OHS } \\
\text { priority by } \\
\text { company } \\
\text { management } \\
\text { (F2) }\end{array}$ & $\begin{array}{l}\text { Periodic OSH } \\
\text { socialization } \\
\text { from the } \\
\text { government }\end{array}$ & $\begin{array}{l}\text { Official policies and } \\
\text { sanctions from the } \\
\text { government }\end{array}$ & $\begin{array}{l}\text { The government } \\
\text { gives strict } \\
\text { sanctions against } \\
\text { violations of } \\
\text { OHS } \\
\text { implementation. }\end{array}$ & $\begin{array}{l}\text { Generate a binding } \\
\text { policy for the } \\
\text { company }\end{array}$ \\
\hline $\begin{array}{l}\text { Low culture } \\
\text { and } \\
\text { discipline of } \\
\text { implementing } \\
\text { OHS (F6) }\end{array}$ & $\begin{array}{c}\text { Provide } \\
\text { education / } \\
\text { training } \\
\text { regarding OHS } \\
\text { (regulations, } \\
\text { SOP, PPE) }\end{array}$ & $\begin{array}{l}\text { Establish an OHS } \\
\text { supervisory team } \\
\text { that can provide } \\
\text { better influence to } \\
\text { wear PPE and } \\
\text { implement OHS }\end{array}$ & $\begin{array}{l}\text { Companies } \\
\text { constitute } \\
\text { regulations or } \\
\text { policies related } \\
\text { to the use of PPE } \\
\text { and sanctions }\end{array}$ & $\begin{array}{l}\text { Provide guidance } \\
\text { and always remind } \\
\text { to use PPE and } \\
\text { constitute } \\
\text { regulations } \\
\text { regarding OSH }\end{array}$ \\
\hline $\begin{array}{c}\text { Lack of } \\
\text { knowledge } \\
\text { about OSH } \\
\text { (F3) }\end{array}$ & $\begin{array}{c}\text { Provide } \\
\text { education / } \\
\text { training } \\
\text { regarding OHS } \\
\text { (regulations, } \\
\text { SOP, PPE) }\end{array}$ & $\begin{array}{l}\text { Regular socialization } \\
\text { and monitoring from } \\
\text { the company }\end{array}$ & $\begin{array}{l}\text { Socialization and } \\
\text { training related } \\
\text { to K3 and the use } \\
\text { of PPE }\end{array}$ & $\begin{array}{c}\text { Provide education } \\
\text { / training } \\
\text { regarding OHS } \\
\text { (regulations, SOP, } \\
\text { PPE) }\end{array}$ \\
\hline $\begin{array}{c}\text { Weak } \\
\text { supervision } \\
(\mathrm{F} 4)\end{array}$ & $\begin{array}{c}\text { Improve } \\
\text { supervision of the } \\
\text { implementation } \\
\text { of SMK3 in the } \\
\text { project }\end{array}$ & $\begin{array}{l}\text { Employ experts who } \\
\text { are competent in the } \\
\text { field of K3 (have a } \\
\text { certificate of } \\
\text { expertise) }\end{array}$ & $\begin{array}{c}\text { Improve } \\
\text { supervision by } \\
\text { employing } \\
\text { experts to } \\
\text { supervise the } \\
\text { implementation } \\
\text { of OSH }\end{array}$ & $\begin{array}{l}\text { Safety companies } \\
\text { and foremen must } \\
\text { work together to } \\
\text { supervise the } \\
\text { implementation of } \\
\text { OSH }\end{array}$ \\
\hline $\begin{array}{l}\text { Weak } \\
\text { sanction from } \\
\text { the company } \\
\text { (F5) }\end{array}$ & $\begin{array}{l}\text { Strict sanctions } \\
\text { against violations } \\
\text { of OHS } \\
\text { implementation. }\end{array}$ & $\begin{array}{l}\text { Instill OHS culture } \\
\text { in all divisions in the } \\
\text { company, so that } \\
\text { OHS regulations } \\
\text { including sanctions } \\
\text { can be applied if a } \\
\text { violation occurs. }\end{array}$ & $\begin{array}{l}\text { Provide guidance } \\
\text { to the OHS } \\
\text { supervisor to } \\
\text { take firm action } \\
\text { against those } \\
\text { who violate. }\end{array}$ & $\begin{array}{l}\text { Conduct internal } \\
\text { socialization } \\
\text { within the } \\
\text { company } \\
\text { regarding K3 }\end{array}$ \\
\hline $\begin{array}{l}\text { The } \\
\text { contractor } \\
\text { forced the } \\
\text { workers to } \\
\text { work until } \\
\text { late at night } \\
\text { (F7) }\end{array}$ & $\begin{array}{c}\text { Give a break } \\
\text { before doing } \\
\text { work until late at } \\
\text { night }\end{array}$ & $\begin{array}{l}\text { Providing benefits to } \\
\text { workers so that } \\
\text { productivity remains } \\
\text { optimal }\end{array}$ & $\begin{array}{l}\text { Provide a break } \\
\text { for workers to } \\
\text { rest and provide } \\
\text { additional costs } \\
\text { to workers }\end{array}$ & $\begin{array}{c}\text { Provide } \\
\text { consumption and } \\
\text { additional costs for } \\
\text { workers }\end{array}$ \\
\hline
\end{tabular}




\section{Conclusions}

The seven constraints that most affect the implementation of OHS were ranked based on the highest priority as follows: the limited OHS funds, a low OHS priority by the company management, low culture and OHS discipline, lack of knowledge about OHS, weak supervision, weak sanctions from the company, and the contractor forces to work late into the night. The efforts for improving the implementation of OHS that should be formulated under the rank of the prioritized barriers include: 1) Budget funds related to OHS implementation (i.e., PPE and construction method that is adjusted to the complexity of the project work and risks) must be included in the planning stage. Therefore, the owner understands the existence of OHS costs as the part of the project costs. 2) The government must conduct socialization of policy and strict sanctions against the violent of OHS. Thus, companies will prioritize OSH in every project risk. 3) The company must socialize and strictly supervise their worker to wear PPE in the project site. 4) The contractor needs to appoint a safety staff that collaborates with the foreman to improve the supervision of OHS implementation in the project site. 5) The contractor must conduct a regular briefing to all the divisions in the company to generate OHS culture. Therefore OHS regulation and sanction can be implemented when a violation has occurred. 6) The contractor that employs a worker for late overtime must ensure the health and the condition of the workers and provide additional consumption, in addition to the overtime salary, and keep strict supervision of wearing PPE during in the project site.

\section{References}

1. BPJS. Lonjakan kecelakaan kerja. Available at : https://www.bpjsketenagakerjaan.go.id/berita/5841/Tahun-2015,-Terjadi-105.182Kecelakaan-Kerja.html (2016)

2. J. Nujhani, I. Juliantina, J. Teknik Sipil dan Lingkungan Univ. Sriwijaya 1, 1 (2013)

3. Y.A. Messah, Y.B. Tena, I.M. Udiana, Jurnal Teknik Sipil FST Undana 1, 4 (2012)

4. Y. Kurniawan, Tingkat pelaksanaan sistem manajemen keselamatan dan kesehatan kerja (SMK3) pada proyek konstruksi, studi kasus di kota Semarang (Universitas Negeri Semarang, Semarang, 2015)

5. D.P. Sutjana, Seminar Ergonomi dan K3 2006 (2006)

6. A.A. Basri, Simulation safety management of IBS construction (Universiti Teknologi Malaysia, Malaysia 2008)

7. R. Adawiah, M.I.I. Mardiyono, Work protection for female labors (A study on the implementation of the policy of job safety and health at the PT. Sarikaya Sega Utama in Banjarbaru, South Kalimantan) (Universitas Brawijaya, Malang, 2010)

8. A. Rifandy, Manajemen $K 3$ di industri pertambangan. Available at: https://www.scribd.com/doc/264571416/K3-Tambang (2010)

9. W.I. Ervianto, Manajemen proyek konstruksi (Andi Ofset, Yogyakarta, 2005)

10. P. Pratasis, Jurnal Tekno Sipil 9, 56 (2011)

11. Kementerian PUPR. Penerapan SMK3 di proyek konstruksi kurangi kecelakaan kerja. 2015. Available at: https://www.pu.go.id/berita/view/10539/penerapan-smk3-diproyek-konstruksi-kurangi-kecelakaan-kerja (2015)

12. B. Endroyo, Work safety for building techniques (IKIP Semarang Press, Semarang, 1989)

13. T.L. Saaty, Int. J. Services Sciences 1, 1 (2008) 